\title{
APLIKASI $A L$-TAYSĪR DALAM IBADAT HAJI DAN UMRAH BERDASARKAN KEPUTUSAN MUZAKARAH HAJI KEBANGSAAN
}

\section{The Practice of al-Taysī' in Hajj and 'Umrah Based on the Resolutions of the National Hajj Muzakarah}

\author{
Raihanah Azahari* \\ Ahmad Salahuddin Harun**
}

\begin{abstract}
There is a notion that the hajj pilgrimage is founded on trials and tribulations or mashaqqah and, it is not worthy of a pilgrimage if one does not suffer the exhaustion and fatigue. The hajj is an obligation similar to other acts of worship decreed by Allah upon His servants. Flexibilities (al-taysìr) or relief endowed in Islam for the believers in all obligatory rituals is also present in the hajj. In order to ensure that taysir is practised in accordance with the requirements of Islamic law, certain conditions must be met. This is because taysir is unlike tashil which means "to take easy" so much so that in some
\end{abstract}

\footnotetext{
* Associate Professor, Department of Fiqh and Usul, Academy of Islamic Studies, University of Malaya, 50603 Kuala Lumpur. raihan@um.edu.my

** Master Candidate, Department of Fiqh and Usul, Academy of Islamic Studies, University of Malaya, 50603 Kuala Lumpur. salahuddin. harun@yahoo.com
} 
khilafiyah problems, some parties opt for rukhșah, which is choosing the simplest idea to be carried out without due consideration for the propositions of shar' $i$. This article aims to explain flexibilities or relief and Islamic tasāmuh in the difficult and burdensome aspects of performing hajj routines. By citing several examples of the provisions in taysir which were resolved in the National Hajj Muzakarah, this article concludes that taysir which is practised conforms with Shariah which aims to grant relief and convenience to the pilgrims in performing the obligatory steps in hajj.

Keywords: al-taysīr, hajj, 'umrah, flexibilities, mașlaḥah, mashaqqah

\section{PENGENALAN}

Salah satu objektif penting penetapan syariat adalah untuk mewujudkan kemaslahatan dan menolak mafsadah "جلب المصلحة "ودرء المفسدة Sehubungan itu, al-Shawkani ${ }^{1}$ dalam tafsirnya terhadap ayat 185 yang bermaksud: "Allah menghendaki kamu beroleh kemudahan dan ia tidak menghendaki kamu menanggung kesukaran" menjelaskan, "ayat ini menunjukkan, memberi kemudahan adalah salah satu objektif Syariah dan antara kehendak Allah SWT dalam urusan agamaNya". Ini juga ditegaskan dalam satu hadis daripada Abū Hurayrah yang diriwayatkan oleh alBukhari:2

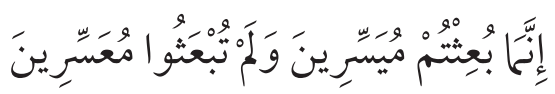

Terjemahan: "Sesungguhnya (wahai Muhammad) kamu diutus untuk memudahkan dan bukan untuk

\footnotetext{
1 Muhammad Ibn 'Alī Ibn Muḥammad al-Shawkānī, Fatḥ al-Qādir, vol. 1 (Dimashq: Dār al-Fikr, 2008), 239.

2 Hadith al-'Arabiy al-lazi Baala fi Masjid al-Nabawi, al-Bukhari, Kitab al-Adab, Bab Qawl al-Nabi (SAW), Yassiru wala Tu'assiru (30/8), Bil 6128.
} 
menyusahkan."

Daripada ayat dan hadis di atas, dapatlah disimpulkan bahawa Islam amat menjaga kesejahteraan penganutnya dengan memudahkan mereka dalam banyak urusan, asalkan mereka tetap taat kepada Allah dan Rasul-Nya. Islam juga tidak akan membebankan penganutnya dengan sesuatu takklif melainkan apa

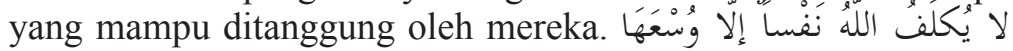
(al-Baqarah 286).

\section{DEFINISI $A L-T A Y S \bar{I} R$}

Al-Taysìr dari segi bahasa berasal dari perkataan yassara yang bererti lembut, lentur, fleksibel, tertib dan dapat digerakkan. ${ }^{3}$ Menurut al-Mawsu'ah al-Fiqhiyyah, ${ }^{4}$ al-taysì $r$ adalah kata terbitan dari perkataan yassara, dan perkataan al-yusr yang bermaksud lembut dan fleksibel. Al-Taysir merupakan antonim bagi perkataan al-'usr yang bererti sukar dan susah.

Dari segi istilah terma al-taysīr ini adalah sesuatu yang dinisbahkan dengan limitasi kemampuan yang dimiliki oleh manusia apabila berhadapan dengan kesulitan dan kesukaran. Kemudahan ini merupakan satu kelonggaran yang diberi oleh syara' kepada mukallaf ketika melaksanakan perintah tanpa dibebani oleh kesulitan dan kesukaran. ${ }^{5}$ Menurut para ulama usul, al-taysīr adalah menjadikan sesuatu itu mudah dan dapat dikerjakan serta tidak menyulitkan. ${ }^{6}$ Hal ini sesuai dengan firman Allah SWT di dalam Al-Quran (al-Baqarah 2: 185) yang

3 Ibrāhīm al-Madhkūr, al-Mu 'jam al-Wāṣit, vol. 2 (Miṣr: Dār alHadīth, 1972), 1064; Aḥmad Ibn Muḥammad Ibn 'Alī al-Muqrī alFayyumī, al-Miṣbāh al-Munīr fì Gharīb al-Sharh al-Kabìr, vol. 2 (Bayrūt: Dār al-Kutub al-'Ilmiyyah, 1994), 850-851.

4 Wizārah al-Awqāf wa al-Shu'ūn al-Islāmiyyah, Mawsū'ah Fiqhiyyah, vol. 13 (Kuwait: Wizārah al-Awqāf Wizārah al-Awqāf wa al-Shu'ūn al-Islāmiyyah, 1988), 112.

5 'Usamah Mahmūd Qana'ah, Fiqh al-Taysīr fì al-Sharī'ah alIslāmiyyah (Dimashq: Dār al-Muștafā, 2009), 32.

6 Wizārah al-Awqāf wa al-Shu'ūn al-Islāmiyyah, Mawsū'ah Fiqhiyyah, vol. 14, 211. 
bermaksud: "Allah SWT menghendaki kemudahan dan tidak menghendaki kesukaran bagimu".

Kesimpulannya, al-taysīr bermaksud pensyariatan hukum yang bertujuan memelihara keperluan mukallaf dan kemampuannya dalam melaksanakan perintah dan menjauhi larangan Allah tanpa meninggalkan hukum-hukum asas syariat Islam.

\section{NAS AL-QURAN DAN AL-HADIS TENTANG $A L$-TAYSİR}

Al-Taysìr dapat difahami melalui nas-nas yang jelas di dalam alquran dan al-hadith. Para sahabat juga turut mengamalkan altaysir dalam dalam kehidupan seharian mereka setelah kewafatan Baginda SAW. Di antara dalil-dalil yang menjelaskan tentang altaysīr ialah:

Firman Allah SWT dalam surah al-Baqarah ayat 185:

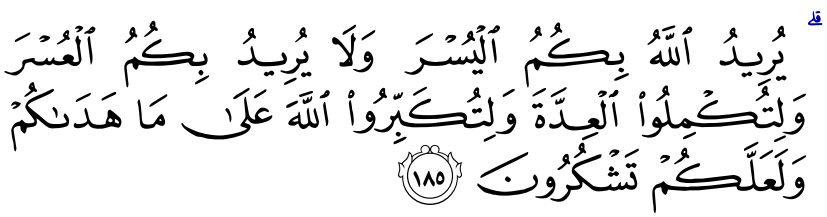

Berdasarkan ayat ini, al-Qurțūbi $\overline{1}^{7}$ menjelaskan, kemudahan itu ialah harus tidak berpuasa ketika musafir dan kepayahan itu ialah berpuasa ketika musafir. Al-Dalalahnya adalah umum merangkumi taklif lain dalam syariat Islam, sepertimana firman

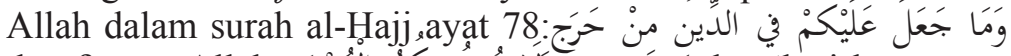

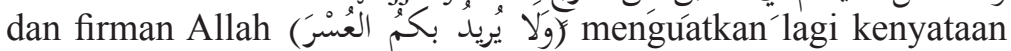
bahawa Dia (Allah) menghéndákki kemudahan bagi hambaNya.

Kemudiannya, dalam surah, al-Nișa' ayat 28 Allah SWT

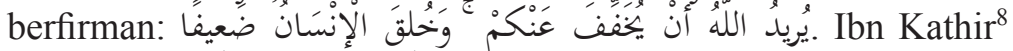
menyatakan áyat ini bermáksud "Allah menghendáki keringanan kepadamu" dalam semua syiarNya, perintahNya, laranganNya, tegahanNya dengan apa yang termampu bagi kamu, selanjutnya ayat yang bermaksud "dan manusia dijadikan bersifat lemah"

$7 \quad$ Abī Wālid Muḥammad Ibn Aḥmad Ibn Muhammad Ibn Ahmad Ibn Rushd al-Qurțūbī, al-Jāmi ' li Ahhkām al-Qur'ān, vol. 1 (Qāhirah: Dār al-Rayyān li al-Turāth, t.t.), 657.

8 Ibn Kathīr, Tafsìr al-Qur'ān al- 'Aż̄im, vol. 1 (Saudi 'Arabia: Dār alSalām, 2004), 656. 
merupakan satu sandaran kepada keringanan yang diberikan Allah SWT, kerana kelemahan yang terdapat pada diri manusia.

Terdapat hadis-hadis yang menjelaskan tentang taysīr antaranya:

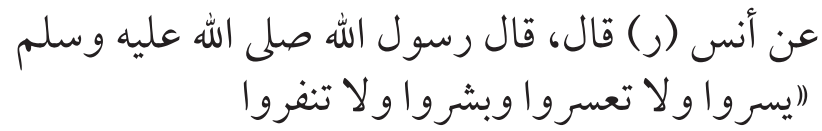

Terjemahan: Dari Anas (RA) berkata, Rasul SAW bersabda: Permudahkanlah dan jangan menyusahkan, gembirakanlah dan jangan menakutkan..." 9

Hadis ini bermaksud pilihlah jalan-jalan yang mempermudah dan meringankan, sama ada dalam hal yang berkaitan dengan ibadah atau mu'amalah bersama manusia. Ini adalah di antara petunjuk Rasulullah SAW diberi pilihan di antara dua perkara, maka Baginda akan memilih perkara yang paling ringan di antara keduaduanya selagi ia tidak membawa kepada dosa. Tetapi jika perkara tersebut boleh membawa kepada dosa maka Baginda adalah orang yang paling jauh dari hal tersebut. Oleh yang demikian, pilihlah sesuatu yang paling mudah untuk kamu pada semua keadaanmu, walau dalam urusan ibadahmu, muamalahmu bersama manusia, bahkan pada semua perkara. Kerana Allah menginginkan kemudahan terhadap hambaNya sepertimana firmanNya dalam surah al-Baqarah ayat 185 yang bernaksud "Allah menghendaki kemudahan bagimu dan tidak menghendaki kesukaran bagimu". Sebagai contoh apabila hendak melaksanakan ibadah haji lebih mudah menggunakan kenderaan dari mengggunakan unta maka yang perlu dipilih adalah menggunakan kenderaan, kerana itu lebih baik. ${ }^{10}$

Dalam satu riwayat lain dari ' $\overline{\mathrm{A}}$ 'ishah $\mathrm{RA}$, beliau berkata:

$$
\text { ما خير رسول الله صلى الله عليه وسلم بين أمرين قط }
$$

9 Muḥammad Ibn Șāliḥ al-'Uthaymīn, Sharh Riyāẹ al-Ṣălihīn alImām al-Nawawī, vol. 3 (T.t.p.: Madar al-Wațān li al-Nashr, 1425H), 587-591, باب الحلم والرفق الأنان

10 Muḥammad Ibn Șāliḥ al-'Uthaymīn, Sharh Riyāẹ al-Ṣăliḥīn alImām al-Nawawī, vol. 3, 587-591. 


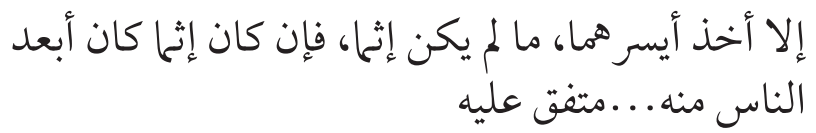

Terjemahan: "Tidaklah Rasulullah SAW diberi pilihan di antara dua perkara kecuali Baginda SAW memilih yang lebih mudah atau ringan selagi yang lebih mudah itu bukan perbuatan dosa. Tetapi apabila terdapat dosa pada perkara itu, maka Baginda adalah orang yang paling jauh dari hal tersebut". ${ }^{11}$

Yang dimaksudkan dengan mudah (al-yusr) di sini ialah mengambil yang mudah berdasarkan asas dan kaedah syarak dalam pengeluaran hukum dan pentarjihan di antara dalil-dalil hukum.

\section{KAEDAH FIQH YANG UTAMA TENTANG $A L-T A Y S \bar{I} R$}

Kaedah utama tentang al-taysir ialah "al-masyaqqah tajlib al-taysī" yang bermaksud "kesulitan menyebabkan adanya kemudahan". Ini bermakna dalam pelaksanaan hukum-hukum tertentu, terdapatnya kesulitan dan kesukaran bagi mukallaf. Oleh yang demikian, syarak memberikan keringanan sehingga mukallaf mampu melaksanakannya tanpa kesulitan dan kesukaran. AlSuyūṭī ${ }^{12}$ membahagikan masyaqqah kepada dua;

1) Masyaqqah yang tidak dapat menggugurkan kewajipan (ibadat) contohnya, penat dan lelah dalam perjalanan haji, ini tidak secara automatik menggugurkan kewajipan haji, kerana masyaqqah ini merupakan hakikat dalam amalan yang dilakukan.

2) Masyaqqah yang dapat menggugurkan kewajipan ibadat. Dalam penjelasannya kepada kaedah ini al-Suyūṭ̂ $1^{13}$ menyatakan, para

11 Shihāb al-Dīn Aḥmad Ibn 'Alī Ibn Hajar al-'Asqalānī, Fatḥ al-Bārī bi Sharḥ Șaḥịh al-Bukhārī (Qāhirah, Dār al-Rayyan li al-Turāth, 1986).

12 Jalāl al-Dīn 'Abd al-Raḥmān Ibn Abū Bakr al-Suyūṭị, al-Ashbah wa al-Naz̄ā’ir (Bayrūt: Dār al-Kutub al-'Ilmiyyah, 1990), 76-83.

13 Jalāl al-Dīn 'Abd al-Raḥmān Ibn Abū Bakr al-Suyūṭī, al-Ashbah wa al-Naz̄ā'ir, 76-83. 
ulama mengeluarkan dari kaedah ini kebanyakan dari rukhsah syarak yang berkaitan dengan tujuh sebab berikut:

a) Musafir

Menurut al-Nawaw $\overline{1}{ }^{14}$ terdapat lapan jenis rukhsah kerana musafir berdasarkan kadar hukum masing-masing. Antaranya syarak memberikan keringanan seperti qasar dan jamak solat serta berbuka puasa pada bulan Ramadan dan menyapu khuf lebih dari sehari semalam.

b) Sakit

Syarak memberikan keringanan seperti tayammum sebagai pengganti wudu', keharusan untuk duduk atau baring atau dengan isyarat ketika solat, harus berbuka puasa pada bulan Ramadan kerana sakit dan wajib qada' apabila sihat, harus mewakilkan haji bagi orang yang tidak berkemampuan melakukannya sendiri dan harus mewakilkan orang lain melakukan lontaran jamrah.

c) Paksaan

Keadaan terpaksa yang merbahaya kepada kelangsungan hidup. Seperti syarak mengharuskan seseorang yang dipaksa untuk melafazkan perkataan kufur sedangkan hatinya tetap beriman kepada Allah SWT.

d) Lupa

Hilangnya daya ingatan terhadap hal-hal yang sudah dimaklumi dan untuk memperolehi ingatannya kembali memerlukan usaha dari mula lagi. Berbeza dengan lalai (sahwu) iaitu lupa yang bersifat sementara dan apabila diingatkan otak akan mampu mengingat kembali suatu yang hilang.

e) Kejahilan

Tidak batal solat orang yang bercakap semasa solat dalam keadaan jahil.

14 Muhammad Maḥmūd al-Muḥammad, al-Qawā 'id al-Fiqhiyyah alKubrā (Bayrūt, Lubnan: Dār al-Kutub al-Ilmiyyah, 1971), 84; Ab̄̄ Zakariyyā Maḥy al-Dīn Ibn Sharf al-Nawawī, al-Majmū 'Sharh alMuhadhdhab, vol. 1 (T.t.p: Dār al-Fikr, t.t.), 507-508. 
f) Kesukaran dan umum al-balwa;

Seperti diharuskan tawaf atau solat dengan kotoran yang sukar untuk dihilangkan yang terkena pakaian yang digunakan untuk solat atau tawaf dan harus tahullul haji dengan dam Ihsar.

g) Kekurangan atau ketidak sempurnaan (naqis)

Seperti orang gila dan bayi yang tidak diberikan taklif oleh syarak.

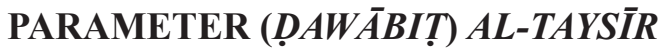

Untuk merealisasikan maqāșid "menolak kesukaran dan memudahkan", syariat telah menetapkan bahawa bukan semua kesukaran boleh membawa kepada kemudahan dalam pelaksanaan hukum. Oleh yang demikian, untuk sesuatu amalan itu menerima al-taysīr ia perlulah memenuhi dawābit berikut:

\section{Al-Taysīr mesti Berasaskan Dalil}

Pengamalan al-taysìr mestilah berasaskan al-Qur'an dan alSunnah. Ianya bertujuan meyakinkan manusia dalam beramal dengan hukum yang diambil daripada kaedah ini. Oleh itu, setiap amalan yang tidak berdasarkan sumber-sumber hukum Islam, maka ia adalah al-taysìr yang tidak diterima. Ini kerana hukum syara' tidak boleh disabitkan dengan istihsān 'aqli tanpa terikat dengan sesuatu dalil. ${ }^{15}$

\section{Pengamalan al-Taysīr Tidak Boleh Melampui Had Keharusan yang Ditetapkan Nas Syara'}

Ini bermaksud tidak harus berlebihan dalam mengambil keringanan dan kemudahan dalam sesuatu hukum yang asalnya memberi masyaqqah kepada mukallaf. Contohnya, tidak harus bagi orang yang boleh solat dalam keadaan duduk untuk berbaring bagi melaksanakan solat kerana ia telah melampaui kadar taysir

15 'Abd 'Allāh Ibn Ibrāhīm al-Tawil, Manhaj al-Taysīr al-Mu'āsir alIslāmiyyah (Riyāḍ: Dār al-Faḍīlah, 2005), 55. 
yang dibenarkan syara' berdasarkan nas-nas yang jelas. ${ }^{16}$

\section{Pengamalan al-Taysīr Mestilah dalam Perkara Furü Syariah}

Pengamalan al-taysìr mestilah berkaitan dengan masalah ijtihadiyyah, iaitu permasalahan yang disabitkan hukumnya melalui kaedah zan. Antara hukum yang boleh menggunakan kaedah ini adalah hukum-hakam berkaitan ibadat, munākahāt, mu'amalat, dan jinayat yang mana tidak terdapat nas yang qat'i atau ijm $\bar{a}$ ' tentangnya. Ada pun permasalahan yang berkaitan dengan usul Syariah seperti permasalahan akidah atau perkara yang sudah dijmma' ' hukumnya, ia tidak boleh mengguna pakai altaysìr dalam penetapan hukum. ${ }^{17}$

\section{Hukum al-Taysīr Yang Diamalkan Tidak Bercanggah dengan Nas}

Sekiranya terdapat nas syarak tentang sesuatu hukum, ia tidak boleh ditinggalkan bagi tujuan mencari hukum lain yang lebih mudah dan ringan. Hal ini berdasarkan dua kaedah yang dibawa oleh ulama usul iaitu: "tiada ijtihad jika terdapat nas"18 dan "ijtihad terbatal apabila ianya menyalahi nas" ${ }^{19}$ Ini kerana mașlahah yang diperoleh daripada konsep al-taysīr bersifat ijtihadi dan tidak sah untuk berpindah daripada nas yang seumpamanya. Al-Ghazzālī menyatakan, "menguna pakai maṣlaḥah dalam keadaan adanya nas, hukumnya adalah batal". ${ }^{20}$ Menurutnya lagi, seseorang mestilah memelihara batas-batas syariat dalam sesuatu hukum dan meninggalkan mașlahah kerana fatwa berdasarkan mașlaḥah adalah perkara ijtihad. Oleh itu, penggunaan konsep al-taysir

\footnotetext{
16 'Abd 'Allāh Ibn Ibrāhīm al-Tawil, Manhaj al-Taysīr al-Mu 'āsir alIslāmiyyah, 55.

17 'Abd Allāh bin Muḥammad al-Rashīd, al-Taysīr fì Manāsik al-Hajj wa al- 'Umrah (Riyāḍ: Maktabah al-Mālik Fahd, 1410 H), 49.

لا اجتهاد مع النص النص

ان الاجتهاد ينقض اذا خالف النص النص

20 Abū Hamid Muḥammad bin Muḥammad bin Muḥammad al-Ṭūṣī, Shifä 'al-Ghalīl fì Bayān al-Shibh wa al-Makhil wa Masālik al-Taḥlīl (Baghdad: Maktabah al-Irshād, 1971), 220.
} 
hendaklah selari dengan kehendak syara' dan tidak bercanggah dengan nas syarak.

\section{Terdapat Darurat atau Masyaqqah yang Memerlukan Penggunaan al-Taysīr}

Mestilah dipastikan kewujudan masyaqqah atau darurat dalam sesuatu permasalahan yang memerlukan penggunaan al-taysir. Ia bagi mengelakkan sesuatu hukum tersebut terbentuk daripada mengikut hawa nafsu. Syariat Islam melarang pelaksanaan hukum yang mengikut hawa nafsu, sebagaimana firman Allah dalam surah (al-Mu'minun 23:71) yang bermaksud "Dan kalaulah kebenaran itu tunduk menurut hawa nafsu mereka, nescaya rosak binasalah langit dan bumi serta segala yang ada".

Al-Qarrafi ${ }^{21}$ menyatakan "adalah haram mengikut hawa nafsu di dalam hukum dan fatwa. Sekiranya mengikut hawa nafsu hukumnya haram, maka mufti perlu memastikan kewujudan masyaqqah dalam sesuatu permasalahan yang berlaku, sebelum mengguna pakai al-taysīr untuk mengangkat kesusahan dan kepayahan yang wujud". al-'Izz 'Abd al-Salam memberikan contoh tentang kewujudan masyaqqah yang terdapat dalam manāsik haji, iaitu diharuskan bercukur bagi golongan yang menghadapi masalah kutu ketika berada di dalam ihram. ${ }^{22}$

\section{Pengamalan al-Taysīr Bukanlah di dalam Bentuk Talfíq yang Dilarang ${ }^{23}$}

Talfiq yang dilarang ialah sengaja mencari-cari hukum-hakam yang mudah dan ringan dari setiap mazhab. Larangan ini sama ada berkaitan dengan hukum tersebut, contohnya menghalalkan sesuatu yang haram seperti zina dan arak, atau ia adalah perkara batil yang tidak berkaitan dengan hukum, tetapi sesuatu yang mendatang seperti tatabbu' al-rukhas. Tatabbu' al-rukhas ialah

21 Wahbah al-Zuhaylī, al-Rukhas al-Shar'iyyah Ahkāmuha wa Dawābituha, (Bayrūt: Dār al-Khayr, 1993), 96.

22 'Izz 'Abd al-Salām, Qawā'id al-Ahkēam fì Mașālih al-Anām, vol. 2 (al-Qāhirah: Maktabah al-Kulliyah al-Azhariyyah, 1991), 10.

23 Wahbah al-Zuhaylī, al-Rukhas al-Shar'iyyah Ahkāmuha wa Dawābituha, 93. 
mengambil sesuatu yang mudah di dalam mana-mana mazhab tanpa sesuatu sebab yang mendesak atau keuzuran.

\section{Al-Taysīr dapat Menghilangkan Masyaqqah atau Kesukaran}

Al-Taysìr bertujuan memperoleh mașlaḥah dalam sesuatu permasalahan hukum. Oleh itu mufti berkewajipan memastikan hukum yang diamalkan memberi kemudahan dan menghilangkan kesukaran dari mukallaf tanpa mencacatkan mașlaḥah serta mendatangkan kemudaratan yang lain. ${ }^{24}$ Contohnya, al-taysìr dalam pelaksanaan hukum melontar sebelum gelincir matahari pada hari-hari tasyriq. Sebahagian ulama' berpendapat bahawa keharusan melontar sebelum gelincir matahari pada hari-hari tasyriq akan memberi kemudahan kepada jemaah dan mengelakkan daripada kesesakan di tempat melontar. Sebahagian yang lain pula berpendapat bahawa ia tidak harus kerana mafsadah yang berlaku selepas gelincir matahari tetap akan berlaku sebelumnya.

\section{Tidak Menyebabkan Kerosakan lain sama ada dalam Jangka Masa Pendek atau Panjang}

Mufti yang ingin menerima pakai al-taysīr dalam fatwanya perlulah memastikan bahawa fatwa tersebut tidak menyebabkan berlakunya kerosakan lain sama ada dalam jangka masa panjang atau pendek. Dia juga perlu memastikan sama ada kerosakan tersebut berkaitan dengan golongan yang meminta fatwa sahaja atau umum untuk semua mukallaf..$^{25}$ Hal ini bertepatan dengan kaedah fiqh" "mengutamakan kemaslahatan dan menolak sebarang bentuk kemudaratan".

\section{Seiring dengan Maqāṣid al-Sharī'ah}

Skop asas syariat Islam adalah untuk memberikan kebaikan kepada

24 Muhammad Sa'ad bin Aḥmad al-Yūbī, Dawābiṭ al-Taysīr al-Fatwā wa al-Radd 'ala al-Mutasahhilīn fìha (Riyāḍ: Dār Ibn al-Jawzī, 1426H), 38-39.

25 Muhammad Sa'ad bin Aḥmad al-Yūbī, Dawābiṭ al-Taysīr al-Fatwā wa al-Radd 'ala al-Mutasahhilìn fìha, 39.

جلب المصلحة ودرء المفاسد 26 
manusia dan menjauhkan dari segala kemudaratan. Maqūṣid alsharī'ah merupakan matlamat yang ingin dicapai oleh syarak dalam pensyariatan hukum. Umumnya, maqāssid ini tertumpu kepada penganjuran mașlahah dan penolakan mafsadah. Menurut al-Shāțibīi, ${ }^{27}$ maqūṣid al-sharī'ah secara dasarnya terangkum dalam tiga kategori iaitu;

i) Kepentingan Darüriyyat. Di bawah kepentingan ini, perkara yang menjadi sandaran kepada manusia, sama ada bersifat keagamaan dan keduniaan akan menjadi pincang seandainya ia tidak dilaksanakan. Justeru memelihara agama, nyawa, akal, keturunan dan maruah serta harta adalah lima nilai kepentingan dalam segala tindakan manusia di dunia.

ii) Kepentingan Hajiyyat merupakan manfaat dan kepentingan di mana jika ia diabaikan boleh membawa kepada kesusahan dan kepayahan hidup manusia, meskipun ia tidak akan membawa kepada kepincangan dan kerosakan hidup. Hajiyyat secara umumnya adalah sokongan terhadap lima nilai utama dalam darüriyyat. Contohnya dalam kes rukhsah. Walaupun solat merupakan kepentingan darüriyyat, kelonggaran diberi bagi mereka yang bermusafir melakukan jama' dan qasar. Walaupun rukhsah bertujuan untuk mengelak daripada kesukaran, manusia masih boleh meneruskan kehidupan secara normal tanpa mengamalkannya.

iii) Kepentingan tahsiniyyat pula merupakan peringkat terbawah dalam susunan maqāṣid al-sharī'ah. Ia merujuk kepada keselesaan yang akan dinikmati oleh manusia yang berkehendak kepadanya. Kepentingan tahsiniyyat adalah satu pembaikan dan kesempurnaan terhadap manusia dalam semua peringkat kehidupan. Tanpa kepentingan tahsiniyyat, kehidupan manusia masih normal walaupun sedikit sebanyak mengganggu keselesaan hidup.

27 Ab̄̄ Isḥāq Ibrāhim Ibn Mūsā Ibn Muhammad al-Lakhmī al-Shātibī, al-Muwāfaqāt fì Ușūl al-Sharī'ah, vol. 2 (Bayrūt: Dār al-Ma'rifah, 1973), 5. 


\section{APLIKASI $A L$-TAYSĪR DALAM IBADAT HAJI}

Bukti wujudnya al-taysīr dalam ibadat haji ialah kewajipan ibadat haji hanyalah diwajibkan sekali seumur hidup ke atas mukallaf yang cukup syarat-syaratnya. Ia merupakan keringanan daripada Allah dan tanda rahmat serta kasih sayangNya kepada hamba-hambaNya. Sekiranya diwajibkan ke atas semua Muslim melaksanakan ibadat haji setiap tahun, maka ia akan memberi kesukaran dan kepayahan kepada golongan yang tinggal jauh dari Mekah dan akan menyebabkan timbulnya banyak masalah di masha 'ir al-haram. Berikut beberapa keputusan muzakarah haji kebangsaan tentang amalan yang berkaitan ibadat haji dan umrah yang mengaplikasi konsep al-taysīr.

\section{Pemakaian Fatrah al-Naqa' bagi Wanita Berhaid Untuk Menyelesaikan Tawaf}

Dalam ibadat haji dan umrah, tawaf merupakan rukun yang wajib disempurnakan oleh setiap orang yang sudah berniat haji atau umrah. Ia tidak boleh digantikan dengan bayaran dam sekiranya tidak dilaksanakan atau disempurnakan. Seseorang yang melaksanakan ibadat haji perlu melaksanakan tawaf ifadah sementara tawaf umrah diwajibkan bagi jemaah yang hadir ke tanah suci bagi melaksanakan ibadat umrah.

Antara syarat sah tawaf menurut pandangan muktamad di dalam mazhab Shāfi'ī adalah seseorang itu mesti suci daripada hadath kecil dan hadath besar. Oleh itu, wanita yang dalam keadaan haid tidak boleh menyempurnakan tawaf pada waktu tersebut dan perlu menunggu sehingga suci bagi menyempurnakan ibadahnya yang masih tertangguh.

Haid adalah darah yang keluar dari rahim wanita secara semula jadi, dalam keadaan sihat, dalam tempoh tertentu. ${ }^{28}$ Jangka masa berada di Mekah terutamanya bagi jemaah yang melaksanakan ibadat umrah, mengakibatkan timbul permasalahan kepada jemaah wanita yang dalam keadaan haid, untuk menyempurnakan umrah

28 Muḥammad Ibn 'Alī Ibn 'Abd al-Raḥmān al-Khāṭib, Risālah fì Ahkām al-Hayd wa al-Nifās wa al-Istihāḍh ('Ammān: Dār al-Fatḥ, 2009), 16. 
ataupun haji mereka sebelum meninggalkan tanah suci untuk menuju ke tanah air ataupun ke Madinah. Hal ini kerana tempoh waktu berada di Mekah yang singkat tidak memungkinkan jemaah untuk terus menunggu waktu suci kerana terpaksa bertolak menuju ke Madinah atau ke Jeddah untuk terus pulang ke tanah air.

Sekiranya tawaf tersebut tidak dapat dilaksanakan kerana jemaah berkenaan berterusan dalam keadaan haid, maka dia tidak dapat menyempurnakan umrahnya dan terpaksa keluar daripada ihramnya dengan bertahallul ihsar. ${ }^{29}$ Ini akan mengakibatkan jemaah kembali ke tanah air tanpa dapat menyempurnakan ibadatnya. Sekiranya ibadat umrah yang dilaksanakan merupakan umrah fardu iaitu umrah kali pertama yang dilakukan dalam hayatnya, maka kewajipan tersebut masih belum gugur dan masih kekal atas zimmahnya. Oleh itu, dia perlu kembali lagi ke Mekah pada waktu yang lain untuk menyempurnakan ibadat umrah bagi menggugurkan kewajipan umrah buat kali pertama yang merupakan suatu yang wajib menurut mazhab Shāfi'ī. Hal ini dilihat bertentangan dengan konsep taysir yang dibawa oleh Islam yang sentiasa memberi kemudahan kepada setiap mukallaf, terutamanya dalam melaksanakan kewajipan yang diperintahkan. Ia juga menyebabkan salah satu daripada prinsip maqāṣid alsharī'ah, iaitu memelihara harta tidak dapat direalisasikan. Hal ini kerana perempuan yang mengalami haid pada waktu tersebut tidak dapat menyempurnakan ibadahnya, dan perlu kembali semula bagi menunaikan kewajipannya, sedangkan ia tidak lagi mempunyai kemampuan kewangan untuk pergi ke Makkah lagi. Ini merupakan satu kesusahan kepada mukallaf tersebut.

Dalam salah satu kaedah fiqh juga dijelaskan sepertimana berikut:

\section{"apabila sesuatu menjadi sempit maka hukumnya menjadi luas." 30}

Kaedah ini bermaksud sekiranya seseorang didatangi kesusahan dan kesulitan dalam melaksanakan hukum syarak, maka diharuskan baginya untuk mengambil rukhșah untuk mengangkat kepayahan tersebut. Dalam isu ini, tempoh menunggu

\footnotetext{
29 Sekiranya dia tidak niat bersyarat ketika permulaan ihramnya.

إذا ضاق الأمر اتسع 30
} 
bagi memastikan seorang perempuan itu suci merupakan satu kesukaran baginya kerana tempoh haid yang berbeza antara seseorang perempuan dengan yang lain. Tidak semua perempuan yang berhaid mempunyai tempoh haid yang singkat. Ada yang tempoh haidnya pendek 1-3 hari dan ada yang 7-10 hari malah ada yang mencapai tempoh maksimum haid 15 hari.

Oleh itu, satu pendekatan taysìr telah diambil oleh Tabung Haji bagi menyelesaikan permasalahan ini. Pendekatan ini diambil berdasarkan pandangan marjuh (muqabil al-azhar) mazhab al-Shāfi‘ yang menjelaskan "sekiranya seorang perempuan kedatangan haid yang berselang-selang dan tempoh keluar darahnya tidak melebihi lima belas hari, maka perlu dilihat dalam dua hal iaitu fatrah ${ }^{31}$ dan naqa' ${ }^{32}$ Fatrah al-Naqa' adalah waktu berhentinya darah (darah bersih dalam dan luar faraj) dalam tempoh haid. Dalam hal ini, para ulama Shāfi ‘ì membincangkan, adakah waktu keluar darah sahaja dikira sebagai haid atau keseluruhannya (waktu berhenti darah di antara tempoh haid) juga dikira sebagai haid. Berdasarkan pandangan al-muktamad, keseluruhan darah itu dikira sebagai haid dan ini adalah pandangan al-azhar. Menurut pandangan muqabil al-azhar, waktu suci (berhenti darah) antara tempoh haid dihukumkan sebagai suci. ${ }^{33} \mathrm{Hal}$ ini juga dijelaskan oleh al-Bujayrimī: ${ }^{34}$

Terjemahan: "Darah yang diselangi dengan naqa' (waktu darah tidak keluar) adalah haid. Inilah pandangan yang muktamad dan pandangan ini dinamakan sebagai pandangan al-sahbi. Pandangan yang kedua adalah waktu naqa' dihukum sebagai suci dan pandangan ini dinamakan sebagai pandangan laqti dan talfiq, dan kedua pandangan ini diamalkan dalam permasalahan solat, puasa dan seumpaman-

31 Fatrah adalah darah terhenti dan tidak keluar lagi semasa dalam tempoh haid.

32 Naqa' ialah tempoh haid darah terhenti dan tidak keluar lagi.

33 'Abd Allāh bin Hijāzī bin Ibrāhīm al-Sharqawī, Hāshiyah alSharqawī 'ala al-Tahrī̄r, vol. 1 (Miṣr: Dār al-Iḥyā' al-Kutub al'Arabiyyah, t.t.), 146.

34 Sulaymān Ibn 'Umar Ibn Muhammad al-Bujayrimī, Hāshiyah alBujayrimī 'ala al-Khāṭib, vol. 1 (T.t.p.: Dār al-Fikr, 1995), 360. 
ya, tidak dijadikan keadaan naqa' itu dihukumkan suci pada kiraan iddah secara ijmā' dan dihalalkan baginya untuk bersetubuh dengan isterinya pada ketika itu (naqa'), dan yang dimaksudkan dengan solat adalah setelah seseorang itu mandi wajib."

Berdasarkan penjelasan ini, dapat disimpulkan bahawa menurut pandangan muqabil al-azhar di dalam mazhab Shāfi '⿳亠丷厂, seseorang itu dikira suci pada waktu naqa' secara mutlak, tanpa ada sebarang ikatan dengan tempoh masa tertentu.

Oleh itu, wanita yang memperoleh waktu naqa' ketika dalam tempoh haid, sekiranya berada dalam keadaan darurat seperti sudah hampir waktunya untuk pulang ke tanah air atau ingin bertolak ke Madinah, bolehlah menggunakan pandangan muqabil al-azhar di dalam mazhab Shāfi 'ī yang menyatakan bahawa orang yang mempunyai waktu naqa' dikira suci untuk melakukan tawaf.

Dalam tempoh tersebut juga, jemaah boleh melakukan ibadatibadat solat, puasa dan lain-lain, kecuali ia tidak dikira untuk menyelesaikan tempoh iddah. Juga dihalalkan baginya bersetubuh pada waktu tersebut. ${ }^{35}$ Sekiranya haid datang kembali dia dianggap berada dalam keadaan tidak suci dan ini menghalangnya dari melakukan semua ibadat yang diharuskan semasa suci.

Walau bagaimanapun, jika jemaah mempunyai masa yang lama untuk sampai kepada waktu wuquf atau untuk pulang ke tanah air, dia dinasihatkan untuk menunggu tempoh sehingga haid berhenti, untuk melakukan tawaf.

Berdasarkan analisis yang telah dilakukan terhadap keputusan muzakarah dan penilaian terhadap dalil-dalil yang dikemukakan, dapatlah disimpulkan, sekiranya seseorang wanita didatangi haid dan berada dalam keadaan ihram, maka dia boleh melaksanakan tawaf jika dia mempunyai waktu naqa'. Pandangan ini dilihat lebih memberi kemudahan kepada jemaah, terutamanya ketika melakukan umrah kerana tempoh berada di Mekah terlalu singkat. Selain menepati dawābit al-taysīr yang ditetapkan, ia juga dapat mengelakkan seseorang daripada pulang ke tanah air tanpa dapat menyempurnakan ibadat haji atau umrah dan dapat memelihara

35 Sulaymān Ibn 'Umar Ibn Muhammad al-Bujayrimī, Hāshiyah alBujayrimī 'ala al-Khātị, vol. 1, 136. 
harta daripada dibazirkan. Penyelesaian ini merupakan satu pemeliharaan terhadap maqūssid al-sharī'ah yang menjadikan harta salah satu daripada lima perkara yang perlu dipelihara.

\section{Wuduk Da'im al-Hadāth}

Berdasarkan mazhab Shāfi'ī dan Mālikī, da'im al-ḥadāth adalah seseorang yang sentiasa berhadath kerana sesuatu yang keluar daripada qubul dan dubur seperti kencing tidak lawas, sentiasa buang angin dan istihadah. Menurut mazhab Hanafĩ dan Hanbalī da'im al-hadāth ialah mereka yang sentiasa keluar sesuatu daripada qubul dan dubur seperti kencing tak lawas, sentiasa keluar angin atau keluar sesuatu daripada badan selain qubul dan dubur seperti hidung berdarah, keluar darah atau nanah daripada badan. ${ }^{36}$

Permasalahan da'im al-hadāth merupakan antara perkara yang sering berlaku kepada jemaah haji Malaysia semasa mengerjakan haji atau umrah. Perubahan cuaca, pemakanan dan umur adalah antara faktor utama yang menjadikan seseorang itu mengalami masalah ini. Seseorang yang mengalami da'im al-hadàth akan menghadapi kesukaran, terutamanya dalam isu membersihkan najis dan juga berwuduk. Ini kerana jarak hotel yang jauh dengan masjid al-haram menyebabkan beberapa syarat antaranya muwalat antara wuduk dan solat bagi pengidap da'im al-hadāth tidak dapat dilaksanakan.

Bagi menyelesaikan permasalahan ini satu pendekatan taysīr telah diambil dengan memilih pandangan pandangan mazhab Shāfi‘ ${ }^{1}$ yang menyatakan golongan da'im al-hadāth wajib berwuduk bagi setiap solat fardu tetapi boleh menggunakan wuduk yang sama bagi solat-solat sunat yang lain. ${ }^{37}$

Dalam hal ini, seseorang yang mengalami da'im al-ḥadāth hendaklah melakukan beberapa perkara berikut iaitu:

\footnotetext{
36 Wahbah al-Zuhaylī, al-Fiqh al-Islāmī wa Adillatuh, vol. 1 (Dimashq: Dār al-Fikr, 1989), 288-289.

37 Laporan Muzakarah Haji Peringkat Kebangsaan kali ke-32 Musim Haji 1436 H (Kuala Lumpur: Bahagian Bimbingan Lembaga Tabung Haji, 2016).
} 
a) Membersihkan najis dari tempat keluar najis dan memakai sesuatu (kapas, tuala wanita, pampers, dan sebagainya) dengan kemas untuk menahan najis daripada terkeluar. Semua perkara tersebut dilakukan setelah masuk waktu solat.

b) Mengambil wuduk setelah masuk waktu solat. Pandangan ini adalah berdasarkan hadis yang diriwayatkan oleh 'Aishah:

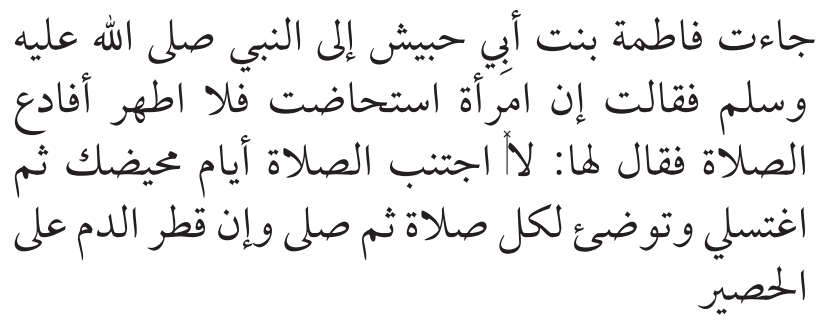

Terjemahan: "Fatimah binti Hubaysh datang menemui Nabi SAW dan bertanya: Aku seorang perempuan istihadah maka aku tidak suci, bolehkah aku meninggalkan solat? Baginda menjawab: Tidak boleh, hendaklah engkau meninggalkan solat pada hari-hari dalam tempoh haidmu kemudian hendaklah engkau mandi dan berwuduklah setiap kali solat sekalipun darah bertitik di atas tikar." 38

Perintah Nabi SAW di dalam hadis ini menunjukkan kewajipan memperbaharui wuduk setiap kali solat bagi golongan da'im alhadāth. Maksud solat dalam hadis tersebut adalah solat fardhu kerana ia merupakan solat yang sempurna pensyariatannya.

Fuqaha Shāfi'ī juga turut membincangkan berkaitan kewajipan membersihkan tempat keluar najis pada setiap kali solat fardu. Mereka menjelaskan, sekiranya alat yang dipakai itu tertanggal dan terdapat kesan najis dan darah pada alat yang dipakai, maka wajib ke atas da'im al-hadāth membersihkan semula farajnya tanpa khilaf. Sekiranya alat yang dipakai tidak tertanggal, masih kemas dan tiada kesan darah, terdapat dua pandangan berkaitannya:

38 Muhammad Ibn 'Alī Ibn Muḥammad al-Shawkānī, Nayl al-Awțār, vol. 1 (Qāhirah: Mațba'ah Mușțafā al-Bābī al-Ḥalābī, 1971), 322323. 
Pandangan pertama yang merupakan pandangan yang asah, "bahawa tempat keluar najis tersebut mesti dibersihkan setiap kali waktu solat". Dan pandangan kedua yang menyatakan "tidak wajib membersihkan tempat najis tersebut kerana tidak mencapai maksud membersihkan tempat keluar najis tersebut". ${ }^{39}$

Berdasarkan pandangan dan hujjah berkaitan isu da'im alhadāth, bagi jemaah haji yang sudah berada di dalam masjid dan sedang menunggu waktu solat, mengguna pakai pandangan mazhab Shāfi'ī memberikan kesukaran untuk mereka. Antara isu yang dihadapi adalah kesukaran untuk membersihkan najis kerana kemudahan tandas dan bilik air di sekitar masjid yang terhad dan sesak serta menyukarkan jemaah untuk membersihkan najis setiap kali masuk waktu. Hal ini dilihat lebih sukar, terutamanya pada hari Jumaat apabila semua jemaah perlu hadir awal ke masjid. Sekiranya jemaah perlu keluar untuk membersihkan najis, maka peluang untuk masuk semula ke dalam masjid hampir mustahil dan ia dilihat mendatangkan masyaqqah kepada jemaah.

Oleh itu, bagi memelihara mașlahah dan menolak masyaqqah kepada jemaah haji, muzakarah telah bersetuju menerima pakai pandangan sebahagian fuqaha' Shafi'yyah dalam isu wuduk bagi da'im al-hadāth iaitu, jemaah perlulah memperbaharui wuduknya bagi setiap solat fardu dan untuk memudahkan, jemaah tidak perlu keluar dari masjid dan boleh menggunakan penyembur untuk mengambil wuduk.

Manakala dalam permasalahan membersihkan najis, muzakarah menerima pakai pandangan muqabil al-asah yang tidak mewajibkan mereka yang da'im al-hadāth untuk membersihkan tempat najis sekiranya alat yang membendung najis dipakai dengan kemas dan najis tidak keluar darinya. Pandangan ini dilihat lebih menjaga mașlahah dan memberi kemudahan kepada jemaah bagi melaksanakan ibadah di tanah suci.

39 "Pandangan FuqahaTentang Wuduk Daim al-Hadath", Laporan Muzakarah Haji Peringkat Kebangsaan kali ke-32 Musim haji 1436H (Kuala Lumpur: Bahagian Bimbingan Lembaga Tabung Haji, 2016), 10. 


\section{Fleksibiliti Masa Untuk Melontar Jamrah}

Para ulama' telah bersepakat bahawa harus melontar jamrah sebelum gelincir matahari pada 10 Zulhijjah, bahkan paling afdal dilakukan setelah terbit matahari kadar segalah/pada waktu duha. ${ }^{40}$ Mereka juga bersepakat tentang hukum sah melontar pada hari tasyriq selepas gelincir matahari sama ada ia dilakukan setelah solat zohor ataupun sebelumnya. Bahkan ia merupakan waktu afdal melontar berdasarkan sunnah Baginda SAW. Namun, yang menjadi perselisihan dalam kalangan fuqaha adalah hukum melontar pada hari-hari tasyriq selepas subuh iaitu sebelum gelincir matahari. Dalam hal ini para fuqaha berbeza pandangan tentang permulaan waktu melontar ketiga-tiga jamrah pada harihari tasyriq, iaitu 11, 12 dan 13 Zulhijjah: ${ }^{41}$

Abū Hanifah dalam riwayatnya yang masyhur, Mālikī, Shāfi‘̄ dan Ahmad berpendapat bahawa tidak harus melontar jamrah sebelum gelincir matahari pada keseluruhan hari-hari tasyriq, dan sesiapa yang melontar sebelumnya dikehendaki mengulangi semula lontaran tersebut. Dalam riwayat yang lain, Abū Hanifah mengkhususkan larangan tersebut pada hari pertama dan kedua hari-hari tasyriq sahaja dan tidak pada hari yang ketiga. ${ }^{42}$

Ibn 'Abbas, Ibn Zubair, Tawus dan Abū Hanifah dalam riwayat yang tidak masyhur pula berpendapat bahawa diharuskan melontar sebelum gelincir matahari pada hari-hari tasyriq. Pandangan ini turut dipegang oleh al-Juwayni, al-Rafi' $i$ dan alIsnawi daripada mazhab Shāfi' $\overline{1}$. Manakala golongan ketiga meskipun mengharuskan lontaran jamrah dilakukan sebelum gelincir matahari pada hari tertentu dari hari-hari tasyriq tetapi berbeza pandangan tentang hari yang diharuskan tersebut:

i) Ibn 'Abbas dan Abū Yusuf dalam salah satu pandangannya

\footnotetext{
40 Al-Nawawī, Yahya bin Sharaf, al-Idah fi Manāsik al-Hajj wa al'Umrah (Makkah: Maktabah al-Imdadiyah, 2010), 312.

41 'Alī Ibn Nașīr al-Shal'an, al-Nawāzil fì al-Hajj (Riyāḍ: Dār alTawhīd li al-Nashr, 2010), 490.

42 Ḥamid bin Musfir al-Ghāmidī, "al-Taysīr fì Wājibāt al-Hajj”" (Disertasi Sarjana, Universiti Umm al-Qura, Makkah, 'Arab Saudi, 1419 H), 210.
} 
menyatakan harus melontar sebelum zohor pada 12 Zulhijjah bagi golongan yang ingin melaksanakan nafar awwal.

ii) Abū Hanifah dan salah satu riwayat dari Imam Ahmad ${ }^{43}$ menjelaskan tidak harus melontar sebelum zohor melainkan pada hari yang ketiga belas Zulhijjah sahaja.

Pihak pengurusan haji Tabung Haji pada asalnya berpegang dengan pandangan muktamad mazhab Shāfi'ī yang menetapkan bermulanya waktu melontar bagi hari-hari tasyriq adalah selepas gelincir matahari. Tetapi setelah berlaku tragedi $M u$ 'aisim pada tahun 1990 yang mengakibatkan 1426 jemaah haji meninggal dunia, ${ }^{44}$ pihak Tabung Haji menerima pakai pandangan yang mengharuskan lontaran jamrah dibuat setelah masuk waktu subuh untuk 11 hingga 13 haribulan Zulhijjah. Ini juga merupakan pandangan yang lemah (daif) oleh Imam Isnawi dan Imam Rafi' 'i. ${ }^{45}$

Syeikh Muhammad Nur al-Fathoni ${ }^{46}$ menjelaskan di dalam kitabnya Kifayat al-Muhtadi:

Terjemahan: "Kelimanya melontar pada tiap-tiap hari daripada segala hari tasyriq akan tiga tempat jamrah iaitu Jamrat al-Ula, Jamrat al-Wusta dan Jamrat al-'Aqabah iaitu hari yang ke sebelas, yang kedua belas dan yang ketiga belas, maka masuk waktunya pada tiap-tiap harinya itu daripada gelincir matahari pada harinya dan berkekalan waktu ikhtiyari baginya hingga jatuh matahari harinya dan waktu jawaz itu berkekalan waktunya sama ada

43 'Alī Ibn Nașīr al-Shal'an, al-Nawāzil fì al-Hajj, 490.

44 Lihat laman sesawang http://news.detik.com/internasional/3017064/ peristiwa-maut-selama-musim-haji-di-arab-saudi-dalam-28-tahun

45 Muhammad Syith Muhammad, "Melontar Jamrah dan Permasalahannya," (Kertas kerja, Muzakarah Haji Peringkat Kebangsaan Kali Ke-13, Lembaga Tabung Haji, Kuala Lumpur, $1418 \mathrm{H}), 155$.

46 Muhammad Nūr al-Fațan̄̄, Kifāyah al-Muhtad̄̄ Pada Menerangkan Cahaya Sullam Mubtadi (Fațani: Matba'ah al-Ḥalābī, t.t.), 174. 
melontar itu melontar Jamrah 'Aqabah hari kesepuluh dan melontar segala ayyam tasyriq hingga jatuh matahari ayyam tasyriq, maka inilah qawl yang muktamad dan pada qawl qadim masuk waktunya dengan fajar tiap-tiap hari dan tersebut di dalam Sharh Manāsik al-Khatib telah mengharuskan Imam Haramayn dan Imam Rafi 'i akan melontar beberapa hari tasyriq dahulu daripada gelincir matahari dan dimuktamadkan dia oleh Isnawi."

Dalam kitab Sharh Manāsik al-Kabir oleh Ḥasb Allāh al-Makkī dinukilkan, bahawa;

Terjemahan: "tidak harus melontar jamrah sebelum gelincir matahari bagi lontaran hari tersebut berbeza dengan lontaran bagi hari yang telah berlalu sebagaimana yang dinyatakan sebelum ini, dan apa yang dibawakan oleh musannif itulah pandangan yang muktamad, dan dikatakan sah melontar sebelum gelincir matahari dan makruh hukumnya, dan dijazamkan oleh Rafi'i sebagaimana Imam al-Juwayni dan dimuktamadkan oleh Imam Isnawi dengan katanya ianya ma'ruf di dalam mazhab kami

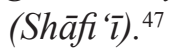

Berdasarkan dalil dan hujjah yang diberikan maka dapat disimpulkan bahawa keharusan melontar setelah masuk waktu subuh dan sebelum gelincir matahari adalah satu bentuk taysir yang dipraktikkan oleh pihak pengurusan haji Tabung Haji. Meskipun pandangan ini lemah tetapi diterima pakai, bertujuan mengelakkan kesesakan yang berlaku di tempat melontar. Ia juga bertujuan menjaga keselamatan jamaah haji Malaysia yang kebanyakan daripadanya agak berumur dan seterusnya mengurangkan risiko yang boleh membahayakan nyawa mereka. Memelihara nyawa juga merupakan salah satu daripada darūriyyat al-khams dalam maqāsṣid al-sharī'ah. Meskipun begitu, jemaah haji digalakkan

47 Muḥammad bin Sulaymān Hasb Allāh al-Makkī al-Shāfi ‘̄i, Hāshiyah 'alā Manāsik al-Kab̄̄r li al-Khāṭib Sharbinī (Qāhirah: al-Mațba'ah al-Wahabiyah, 1894), 92. 
menggunakan kemudahan ini seminimum mungkin. Pada 11 Zulhijjah umpamanya, sekiranya tiada kesukaran maka yang lebih baik bagi jemaah haji, melewatkan lontaran hingga ke sebelah malamnya agar keluar daripada khilaf (khuruj min al-khilaf). ${ }^{48}$

Pemilihan hukum yang menetapkan keharusan melakukan lontaran selepas subuh dilihat bertepatan dengan dawäbit altaysìr yang telah ditetapkan. Ia juga sesuai dengan kaedah fiqh "al-darürah tuqaddar biqadariha" yang bermaksud "keadaan darurat ditentukan mengikut kadarnya". Perbuatan melontar selain daripada selepas subuh juga merupakan sesuatu yang perlu, bahkan dapat mengeluarkan jemaah daripada khilaf yang menyatakan tidak sah melontar sebelum gelincir matahari. Oleh itu, pengambilan waktu melontar selepas subuh sebaiknya hanya digunakan apabila diperlukan sahaja.

\section{Mengumpul (Menjama') Lontaran Jamrah Pada Hari Tasyriq Yang ke 13}

Setelah dijelaskan berkaitan dengan taysìr dalam isu waktu melontar, terdapat satu lagi isu berkaitan taysīr dalam melontar jamrah iaitu keharusan menghimpunkan semua lontaran harihari tasyriq pada hari yang ke 13. Kemudahan ini diamalkan oleh kebanyakan petugas-petugas yang sibuk menguruskan jemaah dan tiada masa berulang alik antara jamrah dengan khemah penginapan. Ia juga diperuntukan bagi golongan yang sudah berusia yang tidak mampu berulang alik setiap hari ke tempat melontar.

Dalam isu ini, pengurusan haji Tabung Haji berpegang dengan pandangan yang menjelaskan tentang keharusan melewatkan lontaran jamrah sehingga ke hari terakhir hari tasyriq dan melontar kesemuanya pada hari tersebut mengikut urutan. Pendapat ini juga merupakan pandangan yang dipegang oleh Abū Yusuf,

48 Hassan Haji Ahmad (Pengerusi Jawatankuasa Ibadat Haji TH/ JAKIM) dalam temu bual beliau bersama penulis pada 5 Disember 2016. 
Muhammad bin Hasan al-Syaibani dari kalangan mazhab Ḥanafī serta pandangan dalam mazhab Shāfi ‘ ${ }^{4}{ }^{49}$

Pandangan ini diambil berdasarkan hadis riwayat Abū alBaddah bin 'Asim bahawa Rasulullah SAW memberi keringanan kepada golongan pengembala untuk melontar sehari dan meninggalkan lontaran pada hari yang lain. Keringanan yang diberikan ini menunjukkan seseorang boleh melontar setelah masuk waktu selama mana hari-hari tasyriq masih berbaki. ${ }^{50}$

Selain itu, seseorang yang menangguhkan lontarannya hingga ke akhir hari tasyriq, masih lagi dikira melakukan lontaran pada waktunya kerana waktu akhir bagi lontaran untuk hari ke 11 dan 12 juga adalah hingga sebelum terbenam matahari 13 Zulhijjah. ${ }^{51}$

Berdasarkan hujjah dan dalil yang diberikan, keharusan menangguhkan lontaran hingga ke hari terakhir daripada hari tasyriq ini dapat memudahkan jemaah yang uzur dan tidak mempunyai kemampuan untuk berulang-alik setiap hari ke tempat melontar. Ia juga merupakan keringanan bagi petugas yang adakalanya terlalu sibuk menguruskan jemaah haji. Kebenaran Nabi SAW kepada golongan pengembala dalam hadis di atas menunjukkan bahawa waktu melontar pada kesemua hari adalah sama. Oleh itu golongan yang menunda lontarannya hingga ke hari akhir, lontaran tersebut masih dikira melontar pada waktunya dan bukannya dianggap sebagai melakukan qada' lontaran.

\section{KESIMPULAN}

Al-Taysìr wujud dalam hukum Islam, terutamanya dalam ibadat haji adalah kerana sebab-sebab yang wujud semasa pelaksanaan hukum ibadat tersebut. Hakikatnya, amalan taysīr dalam ibadat haji telah wujud sejak zaman Baginda SAW lagi dan ia semakin berkembang mengikut peredaran zaman dan waktu dengan berkembangnya masalah dalam pelaksanaan ibadat yang memerlukan al-taysìr di aplikasi. Al-Taysīr memudahkan atau menolak masyaqqah dari mukallaf ialah satu kaedah yang diterima

\footnotetext{
49 'Alī Ibn Nașīr al-Shal'an, al-Nawāzil fi al-Hajj, 531.

50 'Alī Ibn Nașīr al-Shal'an, al-Nawāzil fì al-Hajj, 531.

51 Abū al-Hassan 'Aliyȳ̄ Ibn Habīb al-Māwardī al-Bașriyȳ̄, al-Hāwō al-Kabìr, vol. 4 (Bayrūt: Dār al-Kutub al-'Ilmiyyah, 1414 H), 197.
} 
sekiranya ia tidak bertentangan dengan nas yang sarih atau $i j m \bar{a}$ ' yang muktabar, bertepatan dengan ușūl al-shāri ' al-kulliyah dan maqāșid al-'ämmah, serta meraikan perbezaan masa, tempat, suasana dan keadaan. Ini kerana suasana atau masa yang penuh dengan ujian dan kesusahan bukanlah sama dengan masa yang tenang dan aman, keadaan orang yang takut tidak sama dengan orang yang aman sejahtera dan tidak sama keadaan orang yang berada dalam darurat atau berkeperluan dengan orang yang berada dalam keadaan selesa dan berkemampuan.

Inilah yang dijelaskan oleh Nabi SAW dan diwasiatkan berulangkali kepada para sahabat dengan sabdanya: ${ }^{52}$

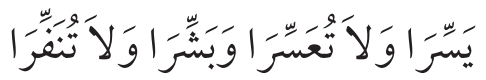

Terjemahan: "Mudahkan dan jangan kamu menyusahkan, gembirakanlah dan jangan kamu menakutnakutkan."

Inilah juga yang disifatkan oleh Allah dalam surah al-Anbiya' ayat 107, yang bermaksud "Dan tidaklah Kami mengutus kamu (wahai Muhammad), melainkan untuk (menjadi) Rahmat bagi semesta alam". Dan kaedah paling utama dalam bab ini ialah almasyaqqah tajlib al-taysī ${ }^{53}$ iaitu kesulitan menyebabkan adanya kemudahan. Ia bermaksud bahawa hukum-hukum yang dalam pelaksanaannya menimbulkan kesulitan dan kesukaran bagi mukkallaf (subjek hukum), lalu syariat memberikan keringanan sehingga mukkallaf tersebut mampu melaksanakannya tanpa kesulitan dan kesukaran.

\section{RUJUKAN}

'Abd 'Allāh Ibn Ibrāhīm al-Tawil, Manhaj al-Taysīr al-Mu 'āsir al-Islāmiyyah (Riyāḍ: Dār al-Faḍīlah, 2005).

52 Wasiat Nabi SAW kepada Abū Musa al-‘Ash'ari dan Mu'az Ibn Jabal ketika mereka akan diutuskan ke Yaman

53 Muḥammad Șiddiq bin Aḥmad al-Burnū, al-Wajīz fì al-'Idah, alQawā 'id al-Fiqhiyyah (Bayrūt: Mu'assasah al-Risālah, 1404 H/1983 M), 129. 
'Abd Allāh bin Hijāzī bin Ibrāhīm al-Sharqawī, Hāshiyah alSharqawī 'ala al-Tahrī̄r, vol. 1 (Miṣr: Dār al-Iḥyā' al-Kutub al-'Arabiyyah, t.t.).

'Abd Allāh bin Muḥammad al-Rashīd, al-Taysīr fì Manāsik alHajj wa al- 'Umrah (Riyāḍ: Maktabah al-Mālik Fahd, 1410 $\mathrm{H})$.

'Alī Ibn Nașīr al-Shal'an, al-Nawāzil fì al-Hajj (Riyāḍ: Dār alTawhīid li al-Nashr, 2010).

'Izz 'Abd al-Salām, Qawā'id al-Ahkām fì Mașālih al-Anām (alQāhirah: Maktabah al-Kulliyah al-Azhariyyah, 1991)).

'Usamah Mahmūd Qana'ah, Fiqh al-Taysìr fì al-Sharī'ah alIslāmiyyah (Dimashq: Dār al-Mușțafā, 2009).

Abī Ishāā Ibrāhim Ibn Mūsā Ibn Muḥammad al-Lakhmī alShātịīi, al-Muwāfaqāt fì Ușūl al-Sharī'ah, vol. 2 (Bayrūt: Dār al-Ma'rifah, 1973).

Abī Wālid Muḥammad Ibn Aḥmad Ibn Muḥammad Ibn Aḥmad Ibn Rushd al-Qurț̄īī, al-Jāmi ' li Ahkē̄m al-Qur'ān (Qāhirah: Dār al-Rayyān li al-Turāth, t.t.).

Abī Zakariyyā Maḥy al-Dīn Ibn Sharf al-Nawawī, al-Idah fì Manāsik al-Hajj wa al-'Umrah (Makkah: Maktabah alImdādiyyah, 2010).

Abī Zakariyyā Mahyy al-Dīn Ibn Sharf al-Nawawī, al-Majmū ‘ Sharh al-Muhadhdhab, vol. 1 (T.t.p.: Dār al-Fikr, t.t.).

Abū al-Ḥassan 'Aliyȳ̄ Ibn Habīb al-Māwardī al-Bașriyȳî, alHāwwì al-Kabīr, vol. 4 (Bayrūt: Dār al-Kutub al-'Ilmiyyah, $1414 \mathrm{H})$.

Abū Hamid Muhammad bin Muhammad bin Muhammad al-Ṭūṣị, Shifä' al-Ghalīl fì Bayān al-Shibh wa al-Makhil wa Masālik al-Tahlīl (Baghdad: Maktabah al-Irshād, 1971).

Aḥmad Ibn Muḥammad Ibn 'Alī al-Muqrī al-Fayyumī, al-Miṣbāh al-Munìr fì Gharīb al-Sharh al-Kabìr, vol. 2 (Bayrūt: Dār al-Kutub al-'Ilmiyyah, 1992).

Hamid bin Musfir al-Ghāmidī, "al-Taysīr fì Wājibāt al-Hajj” (Disertasi Sarjana, Universiti Umm al-Qura, Makkah, 'Arab Saudi, 1419 H). 
Ibn Kathīr, Tafsìr al-Qur'ān al-'Azīm (Saudi 'Arabia: Dār alSalām, 2004).

Ibrāhīm al-Madhkūr, al-Mu 'jam al-Wāṣit, vol. 2 (Miṣr: Dār alHadīth, 1972).

Jalāl al-Dīn 'Abd al-Raḥmān Ibn Abū Bakr al-Suyūṭi, al-Ashbah wa al-Nażā'ir (Bayrūt: Dār al-Kutub al-'Ilmiyyah, 1990).

Laporan Muzakarah Haji Peringkat Kebangsaan kali ke-32 Musim haji 1436 H (Kuala Lumpur: Bahagian Bimbingan Lembaga Tabung Haji, 2016)

Muhammad bin Sulaymān Hasb Allāh al-Makkī al-Shāfi‘̄i, Hāshiyah 'alā Manāsik al-Kabīr li al-Khātị Sharbin̄̄ (Qāhirah: al-Mațba'ah al-Wahabiyah, 1894.).

Muḥammad Ibn 'Alī Ibn 'Abd al-Raḥmān al-Khāțib, Risālah fì Ahkām al-Hayd wa al-Nifās wa al-Istihāọah ('Ammān: Dār al-Fath, 2009).

Muḥammad Ibn 'Alī Ibn Muḥammad al-Shawkānī, Fath al-Qādir, vol. 1 (Dimashq: Dār al-Fikr, 2008).

Muhạmmad Ibn 'Alī Ibn Muhammad al-Shawkānī, Nayl al-Awțār (Qāhirah: Mațba'ah Mușțafā al-Bābī al-Ḥalābī, 1971).

Muḥammad Ibn Șāliḥ al-'Uthaymīn, Sharh Riyậ̣ al-Șāliḥin al-Imām al-Nawawī (T.t.p.: Madar al-Wațān li al-Nashr, $1425 \mathrm{H})$.

Muhammad Maḥmūd al-Muhammad, al-Qawāid al-Fiqhiyyah al-Kubrā (Bayrūt, Lubnan: Dār al-Kutub al-Ilmiyyah, 1971).

Muḥammad Nūral-Fațan̄i, Kifāyah al-Muhtadī Pada Menerangkan Cahaya Sullam Mubtadi (Fațani: Matba'ah al-Ḥalābī, t.t.).

Muhammad Sa'ad bin Aḥmad al-Yūbī, Dawābit al-Taysìr alFatwā wa al-Radd 'ala al-Mutasahhilīn fìha (Riyạ̣̄: Dār Ibn al-Jawzī, 1426H).

Muhammad Ṣiddiq bin Aḥmad al-Burnū, al-Wajīz fì al-'Idah, alQawā'id al-Fiqhiyyah (Bayrūt: Mu'assasah al-Risālah, $1404 \mathrm{H} / 1983 \mathrm{M})$. 
Muhammad Syith Muhammad, "Melontar Jamrah dan Permasalahannya," (Kertas kerja, Muzakarah Haji Peringkat Kebangsaan Kali Ke-13, Lembaga Tabung Haji, Kuala Lumpur, $1418 \mathrm{H})$.

Rita Uli Hutapea, Peristiwa Maut Selama Musim Haji Di Arab Saudi Dalam 28 Tahun http://news.detik.com/ internasional/3017064/peristiwa-maut-selama-musim-hajidi-arab-saudi-dalam-28-tahun, dicapai pada 22 Disember 2016.

Shihāb al-Dīn Aḥmad Ibn 'Alī Ibn Hajar al-'Asqalānī, Fath alBārī bi Sharh Șaḥ̄h al-Bukhārī (Qāhirah, Dār al-Rayyan li al-Turāth, 1986).

Sulaymān Ibn 'Umar Ibn Muhammad al-Bujayrimī, Hāshiyah alBujayrimī 'ala al-Khāțib, vol. 1 (TTP: Dār al-Fikr, 1995).

Wahbah al-Zuhaylī, al-Fiqh al-Islāmī wa Adillatuh (Dimashq: Dār al-Fikr, 1989).

Wahbah al-Zuhaylī, al-Rukhaș al-Shar'iyyah Ahkāmuha wa Dawābituha (Bayrūt: Dār al-Khayr, 1993).

Wizārah al-Awqāf wa al-Shu'ūn al-Islāmiyyah, Mawsū'ah Fiqhiyyah (Kuwait: Wizārah al-Awqāf Wizārah al-Awqāf wa al-Shu'ūn al-Islāmiyyah, 1988). 